\title{
P01.36. Assessment of commercial formulations of mucuna pruriens seeds for Levodopa (L-DOPA) content
}

\author{
A Soumyanath*, T Denne, A Peterson, L Shinto \\ From International Research Congress on Integrative Medicine and Health 2012 \\ Portland, Oregon, USA. 15-18 May 2012
}

\section{Purpose}

Mucuna pruriens (mucuna) seeds contain 3-6\% LDOPA, and have been used in traditional Ayurvedic medicine to treat diseases resembling Parkinson's disease (PD). Pilot studies in PD show that mucuna seed powder has similar effects to conventional levodopa/carbidopa medication. Formulations of mucuna seed are readily available through the internet, and are used by some PD patients as an alternative to conventional levadopa/carbidopa medication. The purpose of this study was to examine the L-DOPA content of a range of popular mucuna products in order to assess the veracity of label claims.

\section{Methods}

Six different brands of mucuna product were ordered through the internet. Certificates of analysis were obtained where possible. A standard amount of each product was extracted using methanol: formic acid for analysis using reversed-phase high performance liquid chromatography (HPLC) with ultraviolet and fluorescence detection. L-DOPA content was calculated using a standard curve prepared using L-DOPA (SigmaAldrich) as reference.

\section{Results}

The claimed L-DOPA content ranged from 25 to $250 \mathrm{mg}$ per dose for the six products. HPLC analysis revealed that only two of the products had L-DOPA values close to the value claimed. The remaining products contained considerably less L-DOPA , $<10 \%$ in two cases, than implied on the label. Certificates of analysis suggested

Oregon Health \& Science University, Portland, USA that not all manufacturers routinely measure L-DOPA content of their mucuna product.

\section{Conclusion}

Four of six products examined showed a large discrepancy between label claim and L-DOPA content, independently measured by HPLC. This finding warrants further investigation as these deficiencies could impact both patients, and the outcome of clinical studies using these products.

Published: 12 June 2012

doi:10.1186/1472-6882-12-S1-P36

Cite this article as: Soumyanath et al.: P01.36. Assessment of commercial formulations of mucuna pruriens seeds for Levodopa (LDOPA) content. BMC Complementary and Alternative Medicine 201212 (Suppl 1):P36.

Submit your next manuscript to BioMed Central and take full advantage of:

- Convenient online submission

- Thorough peer review

- No space constraints or color figure charges

- Immediate publication on acceptance

- Inclusion in PubMed, CAS, Scopus and Google Scholar

- Research which is freely available for redistribution

\section{CiolMed Central}

C 2012 Soumyanath et al; licensee BioMed Central Ltd. This is an Open Access article distributed under the terms of the Creative Commons Attribution License (http://creativecommons.org/licenses/by/2.0), which permits unrestricted use, distribution, and reproduction in any medium, provided the original work is properly cited. 